\title{
Rancang Bangun Sistem Informasi Praktek Kerja Lapangan Berbasis Web dengan Metode Waterfall
}

\author{
S. Thya Safitri ${ }^{1}$, Didi Supriyadi ${ }^{2}$ \\ ${ }^{12}$ Teknik Informatika - ST3 Telkom Purwokerto \\ ${ }^{12}$ Jalan DI. Panjaitan no. 128 Purwokerto 53147, Purwokerto-Jawa Tengah \\ ${ }^{1}$ sisil@st3telkom.ac.id, ${ }^{2}$ didisupriyadi@st3telkom.ac.id
}

\begin{abstract}
Abstrak - Perkembangan teknologi dan komunikasi sangat membantu kinerja dan proses bisnis organisasi. Perkembanganya harus menghasilkan manfaat bagi organisasi dalam memperoleh informasi, serta membantu organisasi dalam menjalankan proses bisnis yang dibutuhkan sehingga membantu pengelola organisasi mengambil keputusan. Perubahan bentuk proses bisnis yang digunakan dengan perkembangan teknologi dan komunikasi diharapkan mampu mendorong organisasi untuk memiliki pengelolaan yang lebih baik. Salah satu proses bisnis yang terjadi pada Sekolah Tingggi Teknologi Telematika Telkom (ST3 TELKOM) Purwkerto adalah pengelolaan kegiatan praktek kerja lapangan (PKL). Pengelolaan kegiatan Praktek Kerja Lapangan di institusi ini masih menggunakan cara manual di sebagian proses bisnisnya, sehingga manfaat dari perkembangan teknologi dan komunikasi tidak sepenuhnya terpakai. Peneliti bermaksud dan memandang perlu untuk mengembangkan sistem informasi Praktek Kerja Lapangan yang menggunakan metida Waterfall. Hasil pengujian menunjukkan bahwa sistem mampu melakukan proses bisnis Praktek Kerja Lapangan dengan mudah tanpa harus menggunakan cara manual seperti registrasi untuk mengikuti PKL, menampilkan informasi yang dibutuhkan dalam kegiatan PKL, memanipulasi data yang digunakan yang akan digunakan dalam kegiatan PKL.
\end{abstract}

Kata kunci - sistem informasi, PKL, metode waterfall

\begin{abstract}
Developments communications and technology are very helpful for performance and business process of the organization. The developments in information technology should result in benefits for the organization in obtaining information, as well as help organization to running the business process required to take the decision. The change in the form of business process used by developments in technology and communication is expected to encourage organizations to have better management. One of the business processes that occur at ST3 Telkom is the Job Training for Students. Management for Job Training activities in this institution still use manual way in most of its business processes, so that the benefits of the development of technology and communication are not fully used. The goal by Research and the sees is need to develop an information system that uses the Job Training method Waterfall. The results show that the system is able to process the Job Training business easily without having to use a manual method such as registration to follow the street vendors, displays the information needed in the activities of street vendors, which are used to manipulate the data to be used in the activities of Job Training.
\end{abstract}

Keywords - information technology, Job Training for Students, Waterfall Method

\section{PENDAHULUAN}

Selain perkuliahan, praktikum, tugas akhir atau skripsi seorang mahasiswa diwajibkan untuk mengikuti Praktek Kerja Lapangan (PKL). Kegiatan PKL ini sangat diperlukan untuk pengembangan pengetahuan mahasiswa. Dengan melakukan PKL diharapkan mahasiswa dapat memahami, menerapkan dan menguasai hal-hal teknis secara langsung sesuai dengan teori yang telah didapatkan. Mahasiswa diwajibkan melaksanakan PKL di lembaga/ instansi/ perusahaan yang erat hubungannya dengan penekanan minat studi yang diambil.

Program mata kuliah PKL merupakan upaya suatu perguruan tinggi untuk mewujudkan profil lulusan program studi dan kompetensi mahasiswa yang lebih unggul dan siap kerja [3]. Kompetensi tersebut adalah antara lain kompetensi pengembangan kepribadian, keilmuan dan keterampilan, keahlian dalam berkarya maupun berinovasi, serta kompetensi kehidupan bermasyarakat berbasis pada pembelajaran aktif student centered learning (SCL). Untuk mencapai tujuan tersebut, lokasi maupun objek pelaksanaan praktek dapat dilaksanakan di suatu organisasi/tempat usaha yang bernuansa wirausaha, instansi swasta, maupun pemerintah.

ST3 Telkom Purwokerto adalah salah satu perguruan tinggi yang melakukan kegiatan PKL setiap tahunnya. Sebelum melakukan PKL Mahasiswa yang mengambil mata kuliah ini akan melewati tahapan - tahapan yang harus diikuti. Proses Pengelolaan Data di ST3 Telkom Purwokerto dalam pelaksanaan PKL belum menggunakan Sistem Informasi yang berbasis komputer, artinya data - data yang ada masih dikelola secara manual. Kegiatankegiatan yang kurang optimal yang dialami oleh Bagian Administrasi Kemahasiswaan (BAK) pada 
saat ini yaitu : pencatatan dan penyimpanan data kurang terstruktur dan kurang rapi, memerlukan waktu yang lama dalam hal pencarian data mahasiswa yang akan melakukan kegiatan PKL dan mahasiswa yang sudah melakukan kegiatan PKL pada tahun sebelumnya, adanya redudansi data sehingga data tidak konsisten, pemborosan Space sehinggga memerlukan tempat yang besar untuk menyimpan data kegiatan PKL. Pengelolaan data proses pendaftaran kegiatan PKL seharusnya dilakukan secara baik dan cepat [4].

Kegiatan tahap awal (administrasi) yang dilakukan oleh mahasiswa masih belum menggunakan sistem informasi yang berbasis komputer, saat ini mahasiswa masih mengisi formulir pendaftaran yang disediakan oleh institusi dan pada tahap mengisi berita acara (absensi) mahasiswa masih dikelola dengan cara yang manual. Dosen Pembimbing saat ini masih belum dapat melihat report dalam jangka waktu tertentu dari setiap mahasiswa .

Penelitian yang akan dilakukan adalah perancangan sistem informasi Praktek Kerja Lapangan yang ditujukan untuk membantu penyelesaian beberapa kendala yang dihadapi oleh pihak-pihak terkait pelaksanaan PKL. Sistem informasi memungkinkan perusahaan untuk mengelola semua informasi, membuat keputusan yang lebih baik, dan meningkatkan pelaksanaan proses bisnis [2]. Diharapkan dengan adanya sistem informasi PKL ini, maka didapatkan dengan mudah informasi-informasi yang diperlukan. Informasi merupakan data yang telah diolah dan berubah menjadi konteks yang berarti dan berguna bagai pemakai akhir [1].

Tujuan penelitian Perancangan sistem informasi Praktek Kerja Lapangan ini adalah dapat membantu tugas BAK untuk mempermudah melakukan pengelolaan data kegiatan PKL dengan mudah dan lebih terstruktur, membantu dosen pembimbing dalam melihat report dengan jangka waktu tertentu dan mempermudah mahasiswa dalam melakukan tahap administrasi dan tahap pengisian berita acara, karena dengan informasi berbasis web ini mahasiswa mampu mengakses nya dimanapun dan kapanpun. Perancangan Sistem Informasi PKL ini diharapkan dapat membantu ST3 TELKOM PURWOKERTO dalam meningkatkan kinerjanya.

\section{METODOLOGI PENELITIAN}

Metode penelitian yang digunakan adalah metode waterfall. Model waterfall dicetuskan pada tahun 1970 sebagai contoh metodologi pengembangan perangkat lunak yang tidak bekerja secara baik [6]. Tahapan pada metode waterfall adalah sebagai berikut.

\section{A. Analisis Persyaratan}

Seluruh kebutuhan software harus bisa didapatkan dalam fase ini, termasuk didalamnya kegunaan software yang diharapkan pengguna dan batasan software. Informasi ini biasanya dapat diperoleh melalui wawancara, survey atau diskusi. Informasi tersebut dianalisis untuk mendapatkan dokumentasi kebutuhan pengguna untuk digunakan pada tahap selanjutnya.

\section{B. Desain Sistem}

Tahap ini dilakukan sebelum melakukan coding. Tahap ini bertujuan untuk memberikan gambaran apa yang seharusnya dikerjakan dan bagaimana tampilannya. Tahap ini membantu dalam menspesifikasikan kebutuhan hardware dan sistem serta mendefinisikan arsitektur sistem secara keseluruhan.

\section{Implementasi}

Dalam tahap ini dilakukan pemrograman. Pembuatan software dipecah menjadi modul-modul kecil yang nantinya akan digabungkan dalam tahap berikutnya. Selain itu dalam tahap ini juga dilakukan pemeriksaaan terhadap modul yang dibuat, apakah sudah memenuhi fungsi yang diinginkan atau belum.

\section{Integrasi dan Testing}

Di tahap ini dilakukan penggabungan modulmodul yang sudah dibuat dan dilakukan pengujian ini dilakukan untuk mengetahui apakah software yang dibuat telah sesuai dengan desainnya dan masih terdapat kesalahan atau tidak.

\section{E. Operasi dan Maintenance}

Ini merupakan tahap terakhir dalam model waterfall. Software yang sudah jadi dijalankan serta dilakukan pemeliharaan. Pemeliharaan termasuk dalam memperbaiki kesalahan yang tidak ditemukan pada langkah sebelumnya. Perbaikan implementasi unit sistem dan peningkatan jasa system sebagai kebutuhan baru.

\section{HASIL PENELITIAN}

Hasil penelitan dengan metode waterfall yang dapat disampaikan adalah sebagai berikut:

\section{A. Analisis Persyaratan}

Tahapan analisis persyaratan ini menghasilkan 2 buah persyaratan, yaitu persyaratan fungsional dan persyaratan non-fungsional. Ditemukan beberapa persyaratan fungsional, yaitu: Sistem Informasi ini dapat membantu BAK mengelola data secara efektif dan terstruktur, dapat mencetak dokumen sehingga tidak terjadi redudansi data, Dosen Pembimbing dapat melihat report keseharian dan dalam jangka waktu tertentu sehingga dapat memantau langsung kegiatan yang dilakukan mahasiswa selama PKL dengan cara melihat berita acara pada Sistem Informasi PKL, Mahasiswa dapat langsung mendaftar, mengisi kelengkapan administrasi didalam Sistem Informasi dan dapat melihat status apabila telah disetujui oleh pihak perusahaan yang diiginkan, mahasiswa dapat mengisi berita acara yang telah disediakan oleh sistem 
informasi , sehingga mempermudah mahasiswa dalam membuat laporan yang akan dibuat pada akhir kegiatan PKL. Sedangkn persyaratan non-functional adalah sebagai berikut aplikasi dapat diakses melalui browser pada desktop PC yang berbasis window atau mobile.

\section{DESAIN SISTEM}

Tahapan desain sistem menghasilkan Desain Aktivitas, Desain Database dan Desain Interface.

Proses bisnis adalah kumpulan kegiatan yang dibutuhkan untuk menghasilkan produk/jasa [5]. Proses bisnis pada kegiatan PKL digambarkan melalui diagram Aktivitas yang ditunjukkan pada Gambar 1.

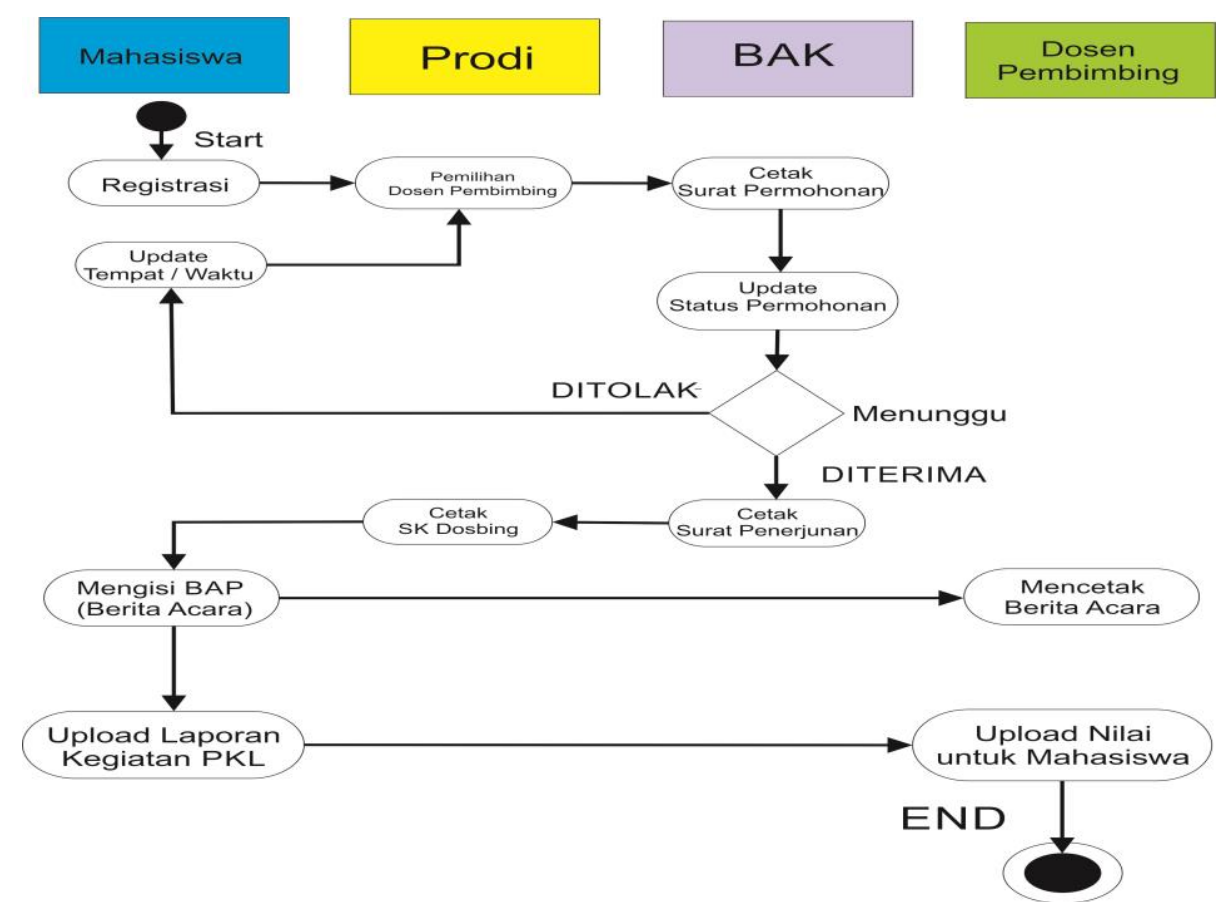

Gambar 1. Diagram Aktivitas

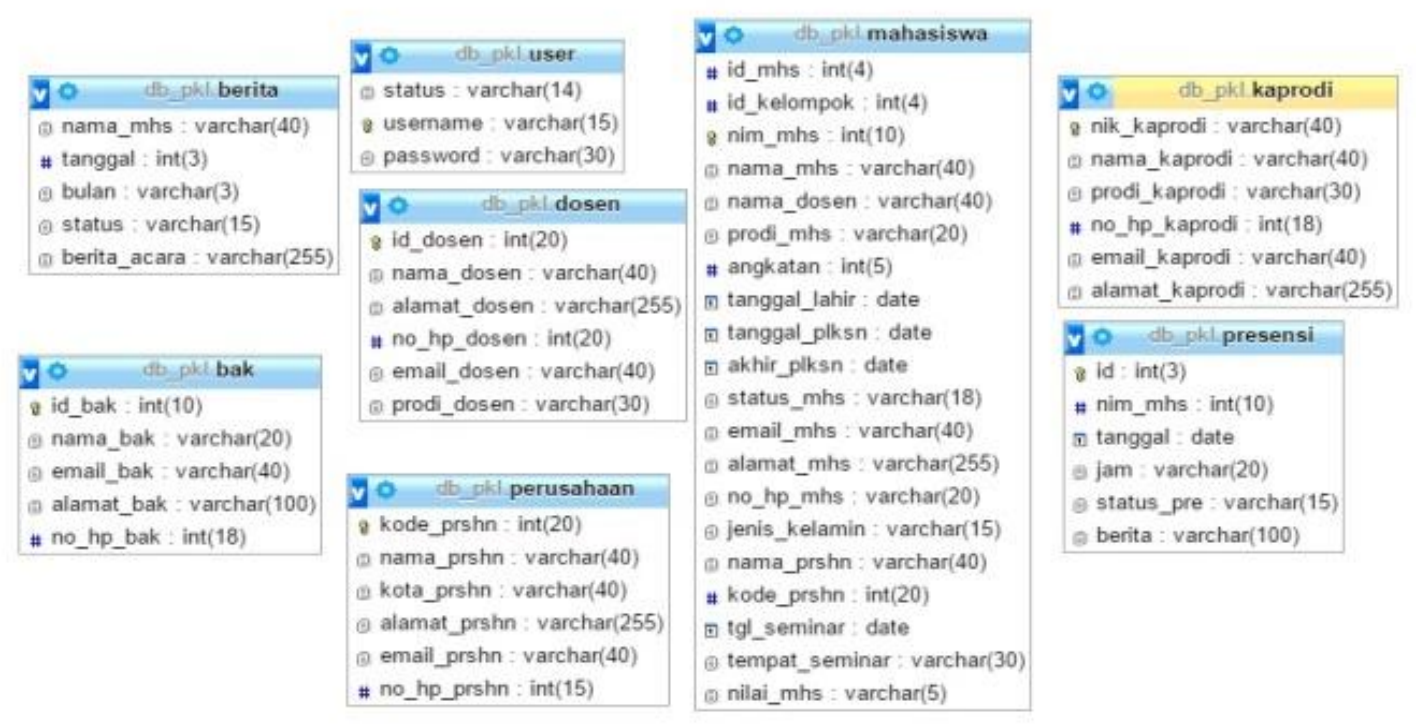

Gambar 2. Skema Database 
Rancang Bangun Sistem Informasi Praktek Kerja Lapangan Berbasis Web dengan Metode Waterfall

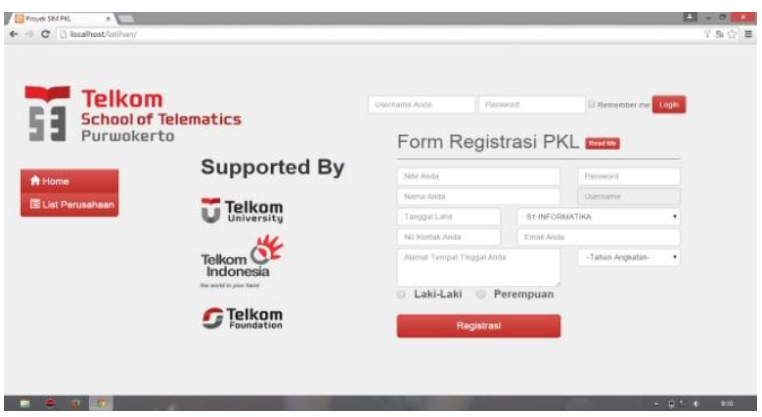

Gambar 3. Desain Halaman Awal

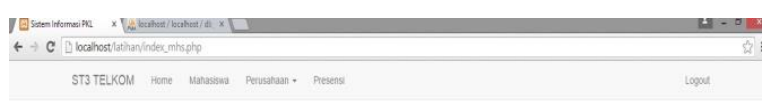

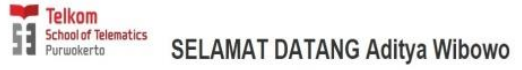

Gambar 4. Desain Halaman Awal Mahasiswa

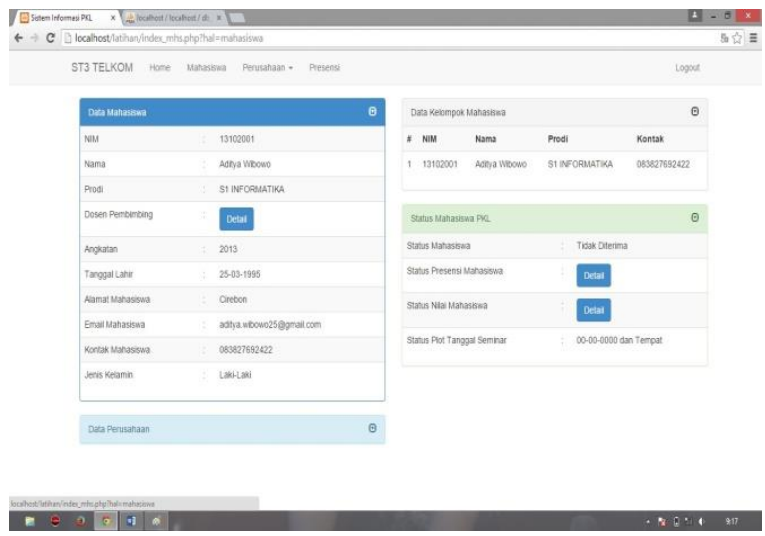

Gambar 5. Desain Halaman Data Mahasiswa

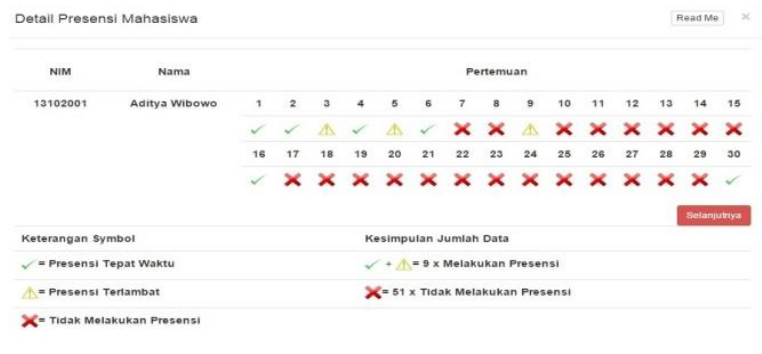

Gambar 6. Desain halaman detail presensi mahasiswa

Detail Nilai Mahasiswa

Close

Gambar 7. Desain Halaman Detail Nilai Mahasiswa
Presensi Kehadiran Mahasiswa PKL

Kamis, 15 Jan 2015 03:20:19

Berita Acara Hari ini

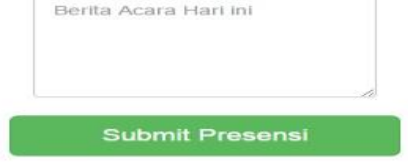

Gambar 8. Desain Halaman Presensi Mahasiswa

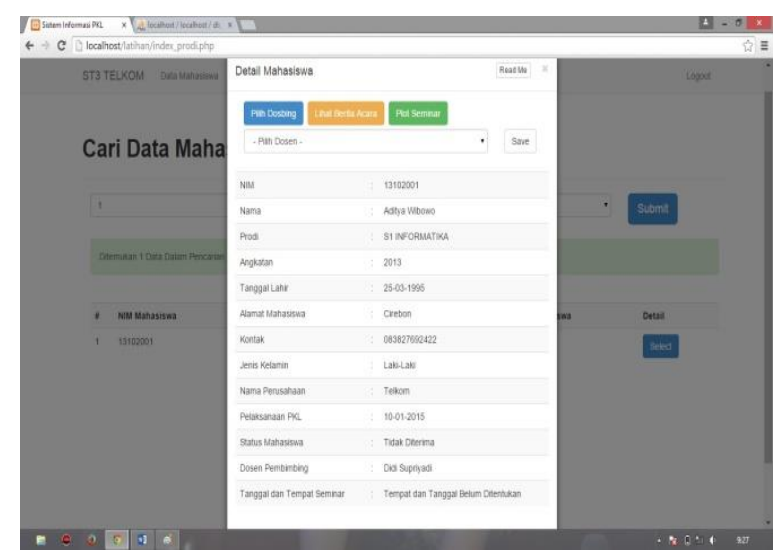

Gambar 9. Desain halaman data mahasiswa di Prodi

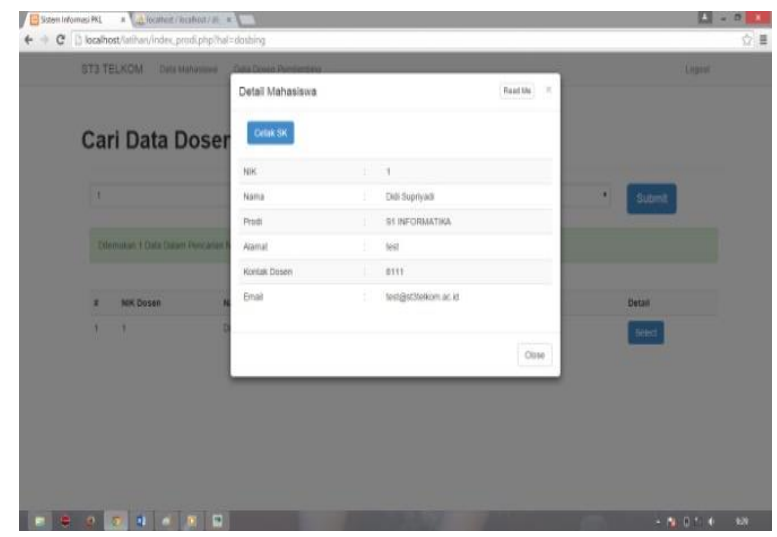

Gambar 10. Desain halaman data Dosbing di Prodi

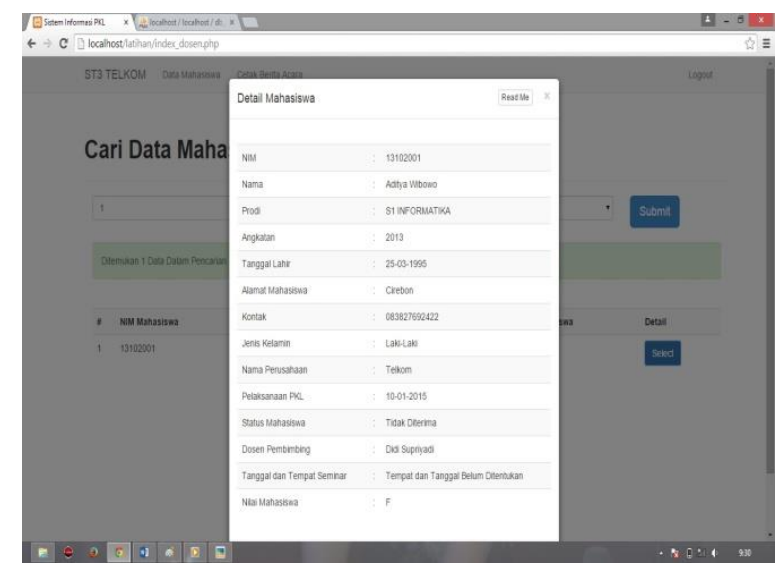

Gambar 11. Desain Halaman Data Mahasiswa di Dosen 


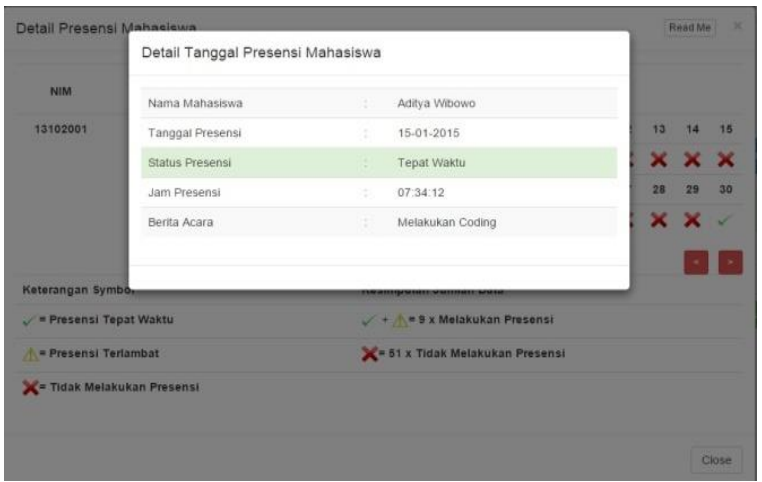

Gambar 12. Desain halaman Berita Acara Dosen Pendamping PKL

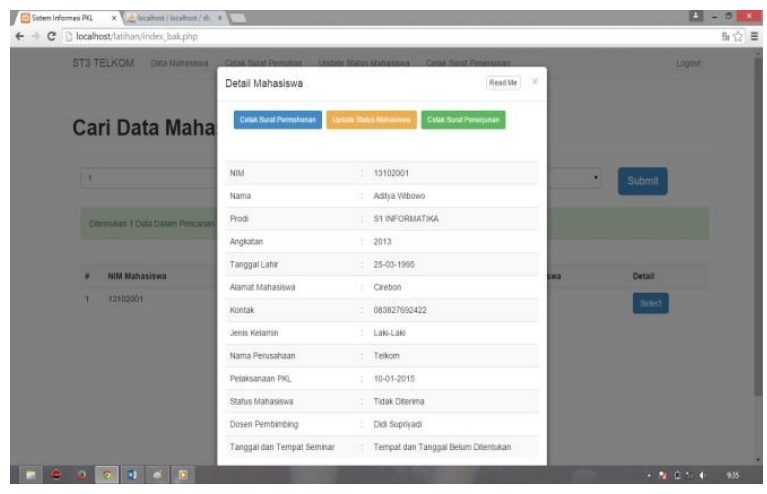

Gambar 13. Desain halaman data mahasiswa di BAK

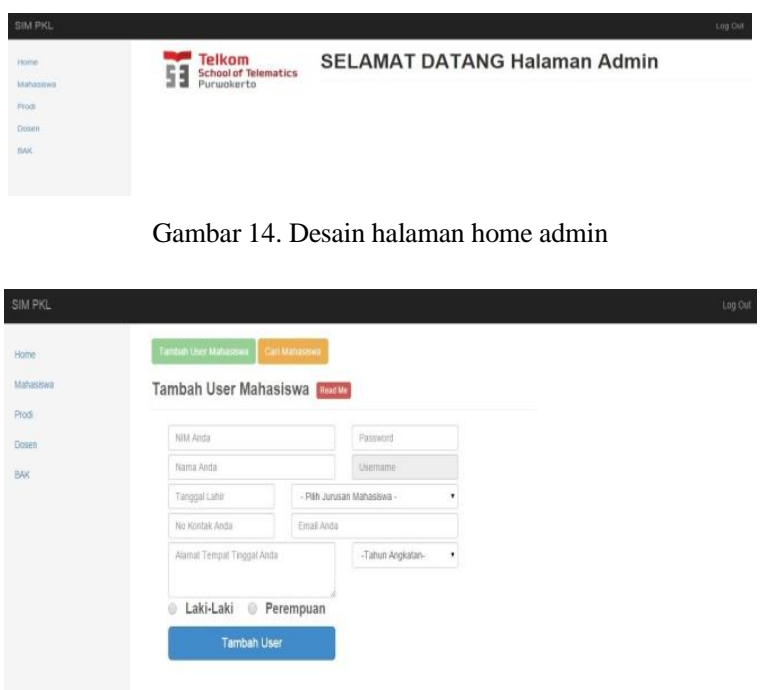

Gambar 15. Desain halaman mahasiswa di Admin

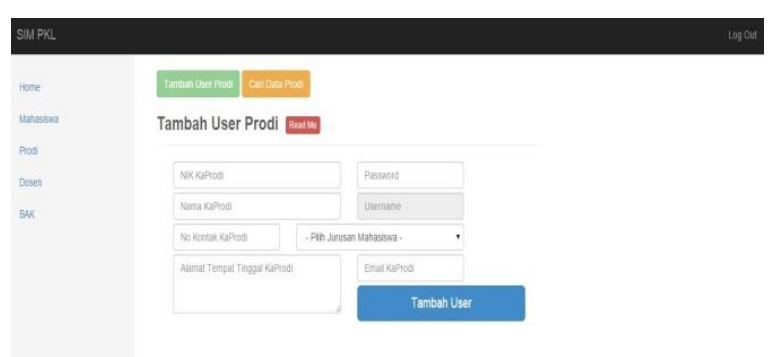

Gambar 16. Desain halaman Prodi di Admin

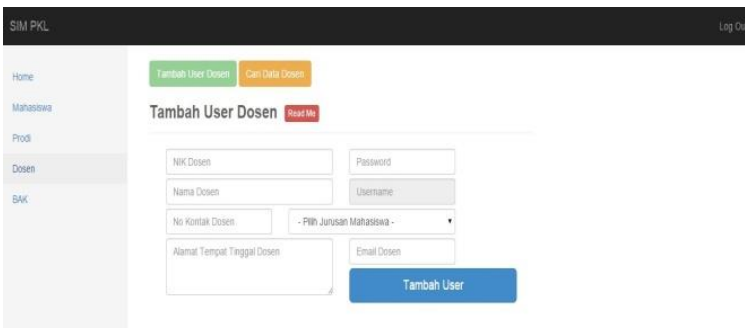

Gambar 17. Desain halaman dosen di Admin

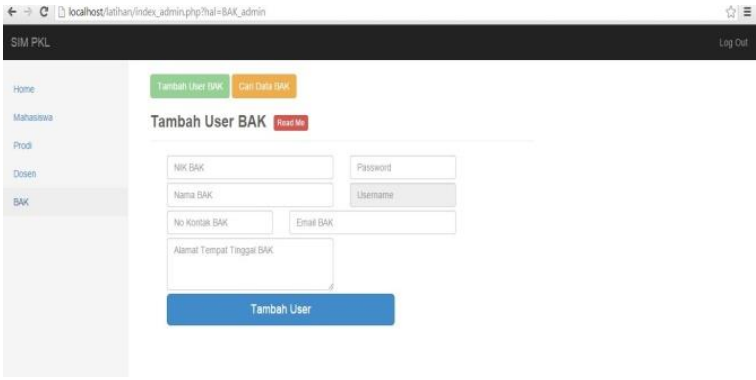

Gambar 18. Desain halaman BAK di Admin

\section{PENUTUP}

\section{A. Kesimpulan}

Proses Bisnis dalam kegiatan PKL di ST3 Telkom Purwokerto sebelumnya masih menggunakan metode manual, beberapa tahapan masih memerlukan waktu yang lama untuk diproses. Pengolahan data nya belum menggunakan sistem informasi yang berbasis komputer. Dengan Sistem Informasi ini mampu mengatasi permasalahan yang ada pada proses bisnis sebelumnya sehingga akan menambah kinerja institusi dalam mengelola kegiatan PKL menjadi lebih baik, efektif dan efisien. Dari hasil pembahasan dan pengujian di atas, maka dapat disimpulkan bahwa sistem informasi Praktek Kerja Lapangan yang dikembangkan di ST3 Telkom ini telah mampu menampilkan informasi dan data yang dibutuhkan dalam kegiatan PKL yang ada meliputi informasi dan data peserta, informasi dan data perusahaan, informasi dan data nilai, informasi dan data presensi peserta, informasi, informasi dan data surat-surat yang dibutuhkan serta menangani proses bisnis yang ada dalam kegiatan tersebut dengan tepat dan baik.

\section{B. Saran}

Berdasarkan kesimpulan pada penelitian ini, maka beberapa saran untuk pengembangan penelitian selanjutnya antara lain sebagai berikut:

1. Sistem informasi Praktek Kerja Lapangan ini membutuhkan banyak sekali validasi data yang dibutuhkan.

2. Sebaiknya dilakukan pengujian secara langsung kepada user/pengguna sistem yang sesungguhnya sehingga dapat diperoleh GAP analisis sistem yang real untuk mengetahui kendala yang dihadapi user. 


\section{DAFTAR PUSTAKA}

[1] Laudon, K.C., and Laudon, J.P., 2012. Management Information Systems : Managing The Digital Firm 12th Edition. Prentice Hall. New Jersey.

[2] Steven Alter., 2002. Information System:Foundation of-E-Business, Mc Graw Hill Inc.

[3] Sinambela, Aci Srihandayani. 2008. Sistem Informasi Pelaksanaan Praktek Kerja Lapangan Berbasis Web pada Jurusan D-3 Ilmu Komputer. Universitas Sumatera Utara.
[4] Rusli, Asep. 2012. Kontribusi Pembelajaran Praktik Kerja Industry Terhadap Prestasi Uji Kompetensi Siswa Teknik Konstruksi Batu Dan Beton Di SMK N1 Sukabumi. Universitas Pendidikan Indonesia.

[5] Opit, Prudensy Febreine. 2012. "Pemodelan Proses Bisnis Pada Divisi Procurement Di Perusahaan X" J@TI Undip, Vol VII, Nomor 3.

[6] Toikkanen, Tarmo. "Don't draw diagrams of wrong practices - or: Why people still believe in the Waterfall model." 9 Sept 2005. 19 Oct 2008. 